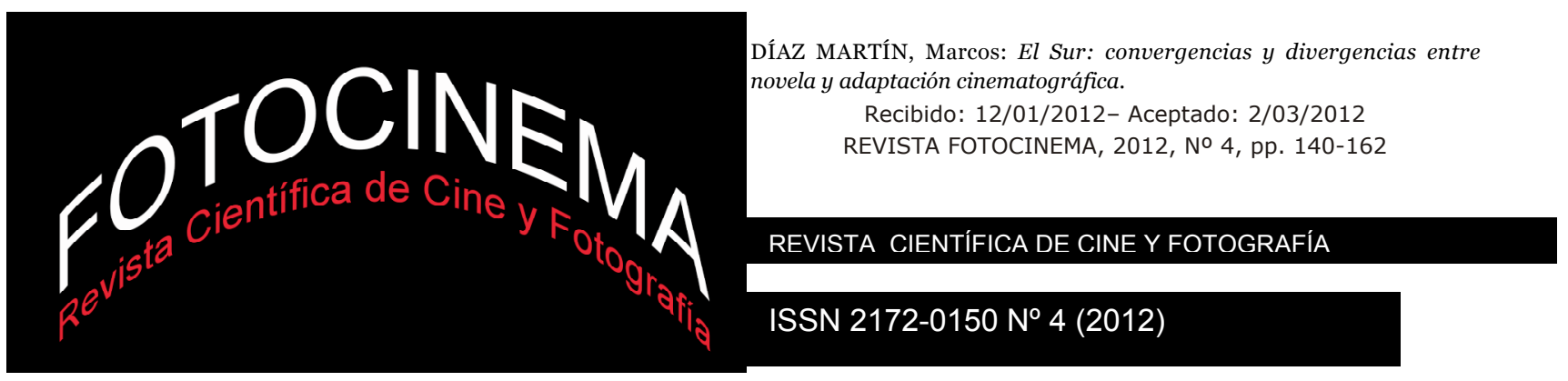

\title{
EL SUR: CONVERGENCIAS Y DIVERGENCIAS ENTRE NOVELA Y ADAPTACIÓN CINEMATOGRÁFICA
}

\section{EL SUR: CONVERGENCES AND DIVERGENCES BETWEEN NOVEL AND FILM ADAPTATION}

Marcos Díaz Martín Universidad Complutense de Madrid

\section{Resumen:}

El presente artículo analiza la relación entre la novela El Sur y su adaptación cinematográfica, atendiendo a la tipología de la adaptación, a sus dimensiones espacio-temporales y a sus diferencias y coincidencias enunciativas y narrativas. Para dicho estudio utilizamos un método analítico e interpretativo, aplicando conceptos teóricos de la relación entre literatura y cine $\mathrm{y}$ recogiendo opiniones $\mathrm{y}$ reflexiones de autores de referencia.

\begin{abstract}
:
This article examines the relationship between the novel $E l$ Sur and its film adaptation, based on the type of adaptation, its space-time dimensions and their differences and similarities in exposition and narrative. For this study we use an analytical and interpretative method, applying theoretical concepts of the relationship between literature and cinema and collecting thoughts and opinions of authors of reference.
\end{abstract}

\section{Palabras clave:}

Víctor Erice; García Morales; relato circular, paisaje anímico.

\section{Key words:}

Víctor Erice; Garcia Morales; circular plot, mood scenary. 


\section{Introducción: ¿̇por qué El sur? metodología del estudio}

El Sur pasa por ser una de las películas más veneradas de la filmografía española y Erice uno de los cineastas más importantes de la cinematografía patria a pesar de su corta obra. Son, además, muchos los trabajos que tratan no sólo la obra completa del autor y su aportación como director, sino otros aspectos más concretos como su relación con la literatura o la pintura, y diversos los estudios dedicados a cada una de sus películas.

El segundo largometraje de Erice, después de El Espíritu de la Colmena, consagró al director español y supuso para él el reconocimiento internacional. Considerada una de las mejores películas del cine español moderno, ejemplar en cuanto a su dirección y realización, polémica en cuanto a su carácter inacabado, fiel en cuanto al espíritu del texto que la inspira, El Sur de Erice supone una experiencia turbadora y en cierta medida poética y metafórica. La película y la novela de Adelaida García Morales suponen un complejo tratado del salto a la madurez, del viaje interior y la relación entre niños, adolescentes y sus referentes paternos.

Encontramos bastantes investigaciones dedicadas al cine del realizador vizcaíno; algunos de dichos estudios suponen la edición de libros completos dedicados al análisis de su particular cine; muchos más han dedicado parte de sus estudios o capítulos dentro de otras publicaciones y tomos al cine de Erice o a algunas de sus películas en concreto. El Sur, como película, como adaptación literaria, como referencia del cine español moderno o como paradigma de cine influido por lo pictórico o lo metafórico, ha sido del interés de investigadores dentro y fuera de nuestras fronteras.

Por la brevedad del texto que la provoca y por el interés de la obra cinematográfica y su especial relación con el primero, en este trabajo procederemos a un estudio completo de la obra, entendido como una comparación entre la novela de Adelaida García Morales de 1985 y la película de Víctor Erice de 1983 y atendiendo a aspectos como la tipología de la adaptación, la fidelidad de la misma, las diferencias y convergencias entre ambas (entre otras, las derivadas del carácter inacabado de la cinta), la enunciación y puntos de vista y las dimensiones espaciales y temporales de ambas. 
Para dicho estudio utilizaremos un método analítico e interpretativo, aplicando los conceptos teóricos y recogiendo opiniones y reflexiones de algunos de los autores antes mencionados e incluso del propio Erice.

\section{El sur de Adelaida García Morales y el de Víctor Erice: contexto y peculiaridades de novela y libro}

El Sur es la primera novela de Adelaida García Morales. El relato, de menos de cincuenta páginas, narra la historia de Adriana -Estrella en la película de Ericey su relación con su familia, más concretamente con su padre.

El texto se estructura sobre un flash back de la protagonista que nos cuenta desde un yo presente, en primera persona, su historia entre los seis y los quince años. La novela se ubica espacialmente en un pueblo del norte, en un espacio no determinado de forma explícita y en una época tampoco concretada.

La novela narra la infancia de Adriana, la pérdida de la inocencia de la misma, el descubrimiento de la vida secreta de su padre, y se caracteriza por evocar un relato intimista, a través del recuerdo y la nostalgia. La narradora de la novela es una persona adulta, de una edad indeterminada y ubicada espacialmente en la casa, en el espacio donde transcurre la mayor parte de la narración.

El relato de García Morales, alineado lingüísticamente cerca del realismo mágico por autores como Rafael Cerrato, es en todo caso un texto intimista, por cuanto refleja las raíces -también el resultado, puesto que la narración corre a cargo de un personaje ya adulto- del personaje protagonista, en este caso Adriana (Cerrato, 2006: 111). La realidad nos viene tamizada, subjetivada por la visión de la protagonista, por una niña, o más bien, por los recuerdos de infancia y adolescencia de una adulta. Conviene recordar que la visión que como lectores obtenemos es no una especie de diario, puesto que el relato está articulado sobre el verbo pasado, y sí una serie de recuerdos, una historia rememorada por una Adriana adulta y de vuelta a La Gaviota.

En la línea apuntada por Cerrato, es cierto que la novela que nos ocupa comparte con ese estilo el interés por mostrar lo irreal y lo fantástico dentro del ámbito de lo real; lo sensorial aparece enmarcado de forma natural en una historia realista. En este sentido, el lirismo de la obra incluye aspectos que 
podemos considerar irreales, como la historia del péndulo y la profesión de zahorí del padre. Veremos luego como estas características conectan, como afirma Cerrato, con la poética del vacío, característica del cine del realizador vasco (Cerrato, 2006: 112).

Sea como sea, el carácter fantasioso de parte de la novela se encuadra dentro de una novela intimista, narrada en primera persona, con un punto de vista único de una narrador diegético pero no omnisciente. Adriana no sabe lo que piensan los otros personajes, el lector por tanto tampoco, ya que no abandona en ningún momento ese punto de vista único.

Epicteto José Díaz establece una relación entre El Sur de García Morales y la visión romántica, en cuanto a que la novela reflexiona sobre la experiencia humana y su falta de base, la experiencia del vacío y del límite (Díaz, 2008: 224).

También Norberto Mínguez Arranz nos da pistas sobre el relato cuando cita a Spiegel para explicar que a partir de la novela decimonónica se ha producido un cambio importante en la manera de descubrir el mundo externo: el trasvase del énfasis desde el objeto al sujeto que establece la mirada y la transformación de la forma de presentar el campo de visión, pasando a una presentación discontinua y fragmentada (Mínguez, 1998:59).

Ambas teorías ven su reflejo en la novela que nos ocupa: El Sur destaca tanto por organizarse en torno a una mirada subjetiva y a la identificación con la protagonista como por una estructura basada en un largo flash back dentro del cual se dan saltos temporales.

El lirismo y el carácter mágico de la obra se ubican en un contexto temporal de postguerra, lo cual aporta la dosis de realismo, de novela de época en que se vislumbra sin problema a uno de los que resultaron perdedores. A pesar de las referencias a ese periodo, la novela no tiene una ubicación concreta que no sea la del norte ni una demarcación temporal concreta que no sea la intuida cuando Adriana nos informa de que su madre no puede ejercer de maestra después de la guerra civil.

Es ésta una historia de descreimiento, reflexión introspectiva y abandono de la inocencia infantil. Lo señalan frases como la siguiente: 


\section{“[...] pensaba entonces que tú eras en un mago” (García, 1985: 5).}

El poder de las ataduras sociales, el cumplimiento de valores religiosos, sociales y de buenas maneras y lo correcto e incorrecto dentro de la óptica de la España de postguerra subyacen detrás del relato intimista. El alto precio que el padre de Adriana tiene que pagar por ceder a la opresión de lo que debe hacer y cómo éste se ve sumido en una vida que no desea y a la que sólo puede hacer frente en pequeñas batallas como el desprecio a Josefa -y con ella de la religión entendida como condicionante moral- muestran un mundo en la novela que abarca mucho más que el viaje interior y la relación de una niña con su idolatrado padre.

El estilo de García Morales huye de lo descriptivo y se encuadra dentro un estilo fundamentalmente narrativo en que los paisajes, los ambientes y los personajes no encuentran una descripción concreta, aunque sí lo haga su personalidad y sus sentimientos, siempre desde la óptica de la protagonista y narradora única. $\mathrm{El}$ aspecto físico de los personajes no interesa tanto a la escritora como sus acciones, a partir de las cuales descubrimos su verdadera esencia.

Historia y discurso en la novela están marcados por lo metafórico y lo lírico. De esa forma la historia, que mezcla lo real con lo fantástico, se ve perfectamente reflejada en un texto en que abundan referencias a la cotidianidad, pero en que caben también términos que expresan estados de ánimo y sensaciones.

En la película veremos cómo la relación entre historia y discurso está plenamente conseguida, siendo la forma de narrar la perfecta para una historia en que la tranquilidad y el desencanto toman el protagonismo.

El Sur de García Morales se mueve entre dos espacios temporales: el pasado, en que trascurre la historia de infancia y adolescencia, y el presente, en que cuenta la historia. Siendo más precisos, podemos dividir ese primer periodo temporal en otros tres y señalar que el primero de ellos abarca la infancia de Adriana, al amor e idolatría de su padre y su relación con otras personas del entorno; el segundo ahonda, coincidiendo con el cambio y encerramiento en sí mismo de Rafael a su vuelta de Sevilla, en el descubrimiento de la vida pasada del padre y el brusco cambio en la relación entre ambos, que finaliza con el suicidio y el viaje de Adriana al sur. La terca parte se ubica en Sevilla y termina con la voz presente -por segunda vez el verbo presente, reflejo de la finalización de una 
historia en flash back- de una Adriana ya adulta y marcada por la ausencia, que decide abandonar aquella casa.

Cristina Martínez-Carazo señala que el mismo acto de enunciación supone un punto de partida diferente:

"La novela, que concluye con el mismo tiempo que se inicia, tiene a Andrea como narrador, y a su padre fallecido como destinatario, por lo que toma un tono de confesión, de descarga personal, de cierta liberación pendiente y de nostalgia desbocada que, después de todo, después de descubrir la verdad y de tanto tragedia, acaba en la nada, en el vacío de una casa abandonada” (Martínez-Carazo, 1997: 191).

El yo narrativo, personalizado en el personaje de Adriana, se abandona sólo cuando trascribe literalmente las cartas de Gloria Valle. Es interesante preguntarse acerca de cómo, en un relato interior, intimista, y que podía interpretarse como imprevisto e improvisado en boca de Adriana adulta, aparecen reflejadas de forma fidedigna e íntegra aquellas cartas. En cuanto a la construcción del relato, señala Carmen Arocena que

"El Sur se caracteriza por la construcción de breves secuencias y momentos, de anotaciones a la vez significantes y decisivas, como las de cualquier diario" (Arocena, 1996: 206).

Como hemos dicho, no compartimos el concepto de diario en la obra, puesto que ésta se narra desde el verbo pasado, pero sí la idea que El Sur de García Morales es una compilación de momentos que, en conjunto, definen unos personajes y una relación. Así, la novela se convierte en una especie de contenedor de escenas con cierta independencia que muestran los cambios en la psicología de los personajes.

El lenguaje de la escritora extremeña se caracteriza por la evocación de pensamientos intimistas, de visiones subjetivadas y emotivas que, además, no se narran desde el presente, lo cual podía hacer de la adaptación una tarea muy complicada. La novela no podría estar más alejada del objetivismo. Veremos que Erice no sólo lo solventa perfectamente, sino que consigue dar a su El Sur un carácter metafórico y simbólico que la hace una película no sólo inteligente y 
bien narrada, sino profundamente emotiva y fiel al espíritu de la novela que la inspira.

Hablando de los personajes, obviamente Adriana y su padre son perfilados de manera mucho más precisa que otros. Sobre la madre -cuya presencia es, como veremos posteriormente, muy diferente a la de la película de Erice- Adriana afirma tener "muy pocos recuerdos durante mi infancia", aunque enseguida comprendemos su carácter amargado y que la relación entre ella y Rafael es más que fría. Otros personajes como Josefa aparecen limitados a su característica principal. Es decir, Josefa es casi una caricatura de la religiosidad más recta y casi sirve de excusa para comprender el carácter anticlerical del padre y su antagonismo.

Una vez introducida la novela de Adelaida García Morales, y de cara a entrar ya en el análisis específico de la adaptación, conviene no olvidar la coeternidad de novela y cinta, ya que la película apareció antes de la publicación de la novela (otra peculiaridad que añadir a la relación entre el texto y su versión cinematográfica). El propio Erice reconoce que tras conocer el relato, y decidido ya a adaptarlo a la gran pantalla, tuvo que imaginar y completar gran parte del mismo a la hora de redactar el guión, porque muchos detalles de lo que finalmente sería el libro de García Morales no estaban todavía definidos. Dos años después del estreno de la película, en 1983, veía la luz la novela.

Quepa destacar desde este momento que compartimos la opinión de Carmen Arocena cuando afirma que la película del realizador vasco

"se refiere a la infancia, al abandono de la ignorancia, al descubrimiento de un secreto, revestido con los valores del mito, a los orígenes, al peso del pasado, porque sus películas hablan fundamentalmente de un solo niño en el que todos podemos reconocernos" (Arocena, 1996: 190).

En efecto, la película de Erice comparte con el relato de García Morales el interés por la infancia perdida, por el abandono de una inocencia que nunca volverá y por el hallazgo de verdades, secretos e intimidades que hacen de la vida un lugar completamente distinto al cómodo territorio de la inmadurez y la ignorancia. 
Con la España de postguerra como telón de fondo, tanto Gómez Morales como Erice hacen un retrato de una época que condiciona a sus protagonistas. También podemos atisbar en el relato un cambio en el modelo familiar tradicional y predominante, un preludio del cambio en esas formas y una desestructuración de la familia en su concepto más habitual.

Los temas del relato no acaban ahí; novela y película ahondan también en la complejidad de la relación paterno-filial, en la dualidad norte/sur, y pasa de puntillas por el tema del incesto - no en la película de Erice debido a que no encontramos el periodo en que Estrella viaja a Sevilla y conoce al que inmediatamente identifica como su hermano-. También se introduce El Sur en los terrenos de lo místico con la historia del péndulo, y en la lucha de los instintos contra las leyes sociales.

Algunas voces defienden que El Sur no es sino una denuncia del estado de la España de postguerra y su fracaso en la refundación de los modelos sociales, ejemplificada por Agustín y su perpetua melancolía. Es evidente que esos temas están presentes, más en la película que en la novela, pero no son los principales de ninguna de las dos, y siempre aparecen como fondo, nunca como argumento principal, en las razones de la definición de los personajes.

\section{El sur, ¿una obra incompleta?}

Rafael Cerrato afirma que el carácter inacabado de El Sur implica una imposibilidad de realizar una explicación global de la película y se apoya en las declaraciones de Fernández Santos en que afirma que es posible que la ausencia de imágenes pudo propiciar que Erice perdiera el control de los signos visuales y poéticos que sí llego a rodar. El propio director afirma en unas melancólicas declaraciones que

"Lo que se quiebra con la falta de la segunda parte es la dimensión moral del relato, el elemento de iniciación y de conocimiento que tiene toda la historia, porque Estrella cumplía el viaje que su padre nunca pudo hacer [...] y que la llevaba a descubrir la identidad de su padre y reconciliarse con la figura paterna. Todo llevaba a un acto de maduración y comprensión del personaje de estrella. 
La historia del tío era también importante, porque tenía para todo el mundo el estigma de la cobardía. Resumía en si cierta dialéctica de la guerra civil, de los hombres que se veían forzados a sumir un compromiso que no era el suyo. Era el personaje más ejemplar de la historia. [...] Había un sur más remoto, evocado a través de los libros de viaje, un sur del sur, un mito literario del sur" (Erice, 2003).

Lo que Erice lamenta es, en suma, la pérdida en la película de una fase del argumento, de aquella que muestra la comprensión, el perdón de la hija hacia su padre, de la propia maduración de la narradora, que sí apreciamos en la novela y que se diluye en la cinta.

Al tiempo, se pierde el deseo del director de ahondar en la problemática de la guerra civil a través del personaje de su tío, obligado a participar en un conflicto que no era el suyo y mutilado física y anímicamente por la contienda.

En cualquier caso esa dialéctica de que habla Erice sí parece estar presente en la película a través de la presencia del padre, que parece encarnar la figura del ateo republicano vencido, incapaz o simplemente sin deseo de adaptarse a una realidad de postguerra que le es profundamente desagradable. Cerrato parece estar en esta línea cuando afirma que

“desde el punto de vista político, El Sur es la historia del expolio que cometieron los franquistas a costa de los republicanos. [...] Erice vuelve a utilizar la mirada femenina como base de la narración, tanto para denunciar la situación de la mujer en la época franquista como para hacer patente una postura estética que le lleva a elegir un lenguaje propio lejos de todo artificio, lenguaje que pretende despertar en el espectador el recuerdo de sus más íntimas emociones" (Cerrato, 2006: 115).

Creemos que el objetivo no es tanto la denuncia de la situación de la mujer como el hecho de acceder a unos sentimientos más íntimos, más personales, tanto del padre como la hija, que si bien se dan en ese contexto de postguerra, superan 
ampliamente en importancia a los primeros tanto en intensidad como en el recuerdo que en los espectadores queda tras el visionado de la cinta.

De hecho, el carácter de Rafael no es provocado por la derrota; ni siquiera el desamor y pérdida parecen son los causantes únicos de esa melancolía. Aunque, desde luego, esos aspectos son fundamentales a la hora de definir el personaje del padre, éste mismo afirma que

"el sufrimiento peor es el que no tiene un motivo determinado. Viene de todas partes y de nada en particular. Es como si no tuviera rostro" (García, 1985: 37).

También creemos que precisamente ese carácter de indeterminación otorga a la película ese toque metafórico que tan interesante y enigmática la hace.

En cuanto al sur metafórico y remoto que Erice quería mostrar mediante el personaje que en principio iba a interpretar Fernando Fernán Gómez, queda lamentable o felizmente limitado a la evocación que en la película hace Estrella a través de las postales del sur y al carácter de las personas sureñas que aparecen en la película.

El hecho de que no se incluya en la película el viaje y la breve estancia en el sur, en Sevilla, hace que la cinta adquiera su tono metafórico. Para el espectador esa mutilación, aunque cierta, es menor en cuanto a que la historia del padre es contada previamente en la escena en que el padre lee -voz en off- las cartas de Irene Ríos. Así, Ángel Fernández Santos es consciente de que

"El Sur que vemos en pantalla tiene belleza y vigor pero también lagunas, huecos, pozos, hilos cortados, cabos sueltos, incongruencias que corroen en parte esa belleza y vigor, pero también de que la parte no rodada está presenta en la sí rodada” (Fernández, 2006).

El Sur es una película con innegables vacios, con ausencias importantes, pero no por ello deja de ser una película completa que, si bien no cierra mucha de las dudas que desde pronto propone, sí supone un viaje metafórico, inacabado pero igualmente bello, a través de la infancia, de la madurez, del conocimiento y del perdón. Por ello estamos en desacuerdo con Leopoldo de Trazegnies Granda cuando afirma que 
"con esta mutilación de la historia el título carece de sentido. Del sur de Adelaida García Morales no queda nada. Es una película oscura y tenebrosa, el sueño luminoso de la niña, lo convierte en la pesadilla del padre" (Trazegnies, 2007).

Opinamos, como Norberto Mínguez Arranz y Sebastián Talavera Serrano, que El Sur de Erice tiene principio y fin en la película, que el hecho de no cerrar una historia no quiere decir dejarla inconclusa, más bien dejar que la historia crezca en la mente del espectador. El sur en la película pasa a ser un concepto de libertad, de huida frente al frío y de liberación y comprensión, alejándose del concepto del sur, más fijo, más claro de la novela. Mínguez Arranz opina que

"El Sur es, en definitiva, la fascinación por lo desconocido, y el final de la película, tal y como hoy la conocemos, contribuye a esa fascinación y encaja formalmente con el tono general de la obra" (Mínguez, 2002: 118).

El sur de Erice, a su pesar seguramente, pasa por ser un lugar místico, poético, delimitado tan sólo por unas postales y las descripciones de la mujer que crió a Agustín. En palabras de Talavera Serrano,

"El carácter inacabado otorga a El Sur parte de su carácter mítico.

[...] Las ausencias, lo incompleto del relato, se ajusta perfectamente al espíritu del mismo" (Talavera, 1997: 40).

Pedro Poyato incluso pregunta:

“¿Acaso el film de Erice no podía concluir sin dar debida cuenta del viaje de Estrella a Sevilla, como sucede en el relato literario? [...] El Sur integra y reelabora, según una poética propia, el texto poético del mismo título de García Morales” (Poyato, 2002: 148).

No es El Sur de Erice la primera ni la última película que deja un final abierto en la mente del espectador y, aunque en este caso por razones bien ajenas a la voluntad del director, no toda película ha de mostrar un final, no todas las historias tienen por qué terminar en el último minuto de proyección. 


\section{Convergencias y diferencias entre texto literario y fílmico}

Ya hemos dicho que la película de Erice busca una identificación con la novela de García Morales a nivel de espíritu, de esencia. Incluso la supresión de una cuarta parte del relato original y las ausencias, omisiones y adhesiones que observamos en la película no pueden con la identificación de texto narrativo y fílmico en su historia y discurso.

Mucho se ha hablado de la dificultad de adaptar un texto tan literario, mezcla de realidad y fantasía, pero la habilidad de Erice lleva a la realización de una obra que, aunque propia y con un estilo reconocible y coherente con su corta filmografía, no deja de ser identificable con la obra de procedencia y deudora del universo de la escritora extremeña.

Los sentimientos que producen novela y película son parecidos, las sensaciones que obtenemos como lectores y espectadores son similares. La principal dificultad es posiblemente llevar a la pantalla una historia tan personal, la confesión de una mujer adulta, el monólogo de una persona en su regreso al hogar, dirigido exclusivamente a su padre.

La novela presenta varias características que la hacen compleja desde el punto de vista de la adaptación; a saber: ausencia de diálogos, voz narrativa en pasado, descripciones basadas en la subjetividad. Los procesos psicológicos son siempre más difíciles de adaptar que la acción y la narratividad pura. En fin, incumple gran parte de los condicionantes que hacen de una novela un modelo de adaptabilidad.

A su favor juega el hecho de adaptar una novela no sólo desconocida en el tiempo de su estreno, sino simplemente inexistente en ese momento. La novela contiene, además, cierta densidad narrativa, cierta condensación de acciones que, siempre vistas desde la subjetividad, dan alguna facilidad a la adaptación cinematográfica. También la duración del texto original supone una ventaja, en principio una novela corta puede adaptarse mejor o, al menos, el tiempo empleado en lectura y visionado se aproximan más.

Aunque ahondaremos en este trabajo más allá de él, el principal criterio a la hora de comparar novela y película suele ser la fidelidad a la primera, la analogía entre ambas experiencias estéticas. En El Sur dicha analogía parece 
completa; el tono poético, intimista y melancólico- aquello que algún autor ha dado en llamar poética del vacío- que imprime el director no hace sino subrayar la historia de pérdida de inocencia y descubrimiento del padre. La identificación es prácticamente total, y la realización no hace sino insistir, dentro de su estilo pausado, tranquilo, contemplativo, en el espíritu de la historia de García Morales.

La adaptación se mueve, en el terreno de la fidelidad y la creatividad, entre la transposición y la interpretación. La fidelidad a la novela, en cuanto a historia y argumentario principal, no impide al autor construir un texto fílmico independiente, propio, con diferencias notables que, si bien no cambian la historia, si la desarrollan por diferentes medios.

El universo de Adelaida García Morales obtiene una respuesta perfecta en una adaptación que sabe llevar ese universo a la pantalla convertido en un texto consciente de su procedencia literaria, pero que por pausado y reflexivo no deja de ser plenamente cinematográfico. Como afirma Epícteto José Díaz, estudioso de la obra de la escritora extremeña,

"uno de los rasgos característicos [de Adelaida García Morales] es la capacidad de crear una "atmósfera» de emociones y percepciones difíciles de explicar, ya que respecto a ellas las palabras solo consiguen una aproximación" (José, 2008: 228).

El tipo de relato de $E l$ Sur literario y fílmico guarda una coherencia estilística palpable: en novela y cinta vemos un lenguaje cercano, aunque profundo y sentimental. Ambos autores huyen de una autoría muy destacada, alejándose de modos de narración en los que la mano del autor está demasiado presente. En ambos reina la tranquilidad, la parsimonia, la contemplación.

La extensión no constituye un problema en cuanto a reducción de material se refiere. Al contrario que en la mayor parte de las adaptaciones, aquí el texto referente es muy corto (apenas supera las cincuenta páginas) y más bien la novela sustituye algunos pasajes por otros, más potentes desde el punto de vista cinematográfico. Entre novela y película se establece por tanto una relación de equivalencia, justificada por una misma historia, una corta extensión de ambas y una ambivalencia en cuanto a acciones y desarrollo, con las diferencias 
propias de una adaptación. Los diálogos en la película no tienen referente en un relato literario organizado en torno a un monólogo interior.

Si bien en la novela no encontramos elementos cinematográficos, entendidos estos como arquetipos narrativos o recursos que hagan pensar en ella como fácilmente adaptable o como fuente de una futura versión cinematográfica, más allá de la intensidad emocional de la historia y el juego que pueda dar por su ubicación espacio temporal y complejidad de los personajes, sí encontramos en la película indicios de una historia de procedencia literaria. Algunos pueden ser la inclusión de la voz en off de una mujer ya adulta durante toda la cinta o la voz en off de otros protagonistas cuando otros personajes leen alguna carta escrita por ellos.

El Sur, la novela, no es en realidad muy plástica en cuanto a la descripción de los personajes se refiere; sí que lo es en cuanto a su naturaleza psíquica, a sus comportamientos y en cuanto a las interrelaciones entre personajes y la influencia de las mismas en la psique de los otros.

\section{Dimensión espacial y temporal}

Tanto el texto novelístico como el fílmico juegan con la indeterminación espacial. Ambos recogen referencias al norte y el sur, pero sólo acotan el espacio en el caso del segundo: sabemos que ese sur, por otro lado metafórico, luminoso, onírico, tiene su ubicación espacial concreta en la ciudad de Sevilla. Así al menos lo recoge el libro en el momento en que Adriana hace su viaje y la película en el momento que Estrella contempla las fotografías que, además, son casi el único referente concreto que obtenemos en la película.

La casa (a dos kilómetros de la ciudad en el libro, a una distancia supuesta en la película) se ubica en un espacio indeterminado, más allá de un paisaje que suponemos castellano y que funciona más como antítesis de un sur luminoso.

Tanto en novela como en película vemos una relación entre el espacio evocado y filmado y la psicología de los personajes. El espacio cumple su función como significante: si hacemos una enorme simplificación, el norte es lo triste, lo seco, lo árido, lo gris. El sur es lo bello, lo alegre, la luz. Es el espacio como estado de ánimo. La novela no es descriptiva en este punto, sí lo es en cuanto a la 
psicología de los personajes. A García Morales le interesan mucho más los personajes y sus interrelaciones que el espacio como algo más que contenedor de significaciones:

“...aquella casa, a dos kilómetros en la ciudad, perdida en el campo, sin vecino alguno. Era muy grande para nosotros, aunque así podía venir tía Delia, tu hermana, a pasar temporadas [...]. También teníamos sitio para Agustina, la criada...” (García, 1985: 5).

Erice comparte con García Morales el gusto por el ambiente como focalizador de emociones; el "paisaje anímico", como lo denomina Antoine Jaime. Esta teoría se hace especialmente patente en las escenas que comentamos: la oscuridad de la habitación de Agustín es la misma de su conciencia. La sordidez de la habitación cercana al paso del tren también lo es.

Las descripciones del interior de la casa son casi inexistentes. La narratividad predomina sobre la descripción, aunque en algún momento se nos hace partícipes de la naturaleza de algún escenario: es el caso de la parte de la novela en que Adriana consigue dar con el agua en medio de un terreno aparentemente seco:

"Recuerdo que me sentía embriagada y que me pareció bellísimo aquel terreno yelmo y plano, sin apenas color, sin plantas ni árboles" (García, 1985: 19).

En esta ocasión, la localización espacial juega un papel inverso al comentado anteriormente: el estado de ánimo en oposición al más triste de los escenarios, un campo aparentemente seco, árido, sin vegetación.

La película puede considerarse descriptiva por su utilización de la cámara y el montaje: planos largos y una cámara que se obstinan en la tranquilidad, en el largo contemplar de los matices, de las localizaciones.

Erice opta por planos amplios en exteriores: el camino y el campo, dando importancia no tanto al lugar exacto de la localización como al tipo de localización rural y poco habitada; y por planos medios y primeros en las localizaciones internas, apoyando la naturaleza intimista del relato.

Un aspecto a destacar al hablar del espacio en la película, más que en la novela, es la relación del tiempo de la misma, en cuanto contexto histórico, con la 
personalidad del padre. Si bien no importa la situación concreta de la acción, si importa a qué se opone: el norte se opone al sur, como la opresión que allí sentía se opone a la supuesta libertad de vivir alejado de aquel que no comparte sus ideales, del vencedor de la guerra civil, en definitiva.

En cuanto al sur, el espacio es definido por unas postales y, sobre todo, por las evocaciones de Milagros: sus descripciones arrojan luz sobre el lugar casi tanto como lo hace su personalidad, su forma de hablar y expresarse.

La película juega con un tipo de espacio con que la novela no puede contar, al menos no de la misma forma: ya desde la primera escena la muerte del padre se presenta en un espacio fuera del cuadro, fuera de la pantalla. Sólo el sonido en off y la presencia casi inmóvil de Estrella nos hacen partícipes de lo que ocurre lejos de nuestros ojos.

El espacio juega también un papel importante en la película a la hora de mostrar los saltos temporales: el camino se hace testigo del paso del tiempo, la pintura en los árboles que delimitan el camino por el que Estrella pasa de niña a adolescente nos muestra de manera brillante el cambio de edad de la protagonista.

En cuanto a su arquitectura temporal, lo más evidente es destacar que El Sur de Erice y de García Morales se edifican sobre dos largos flash back. En ambos textos la información se articula sobre relatos circulares. La historia comienza y acaba en el mismo lugar, también en el mismo tiempo. En novela y película nos situamos inicialmente en la edad de 15 años, aunque tanto la narradora de la novela como la voz en off de la película nos demuestren que la voz narradora es en realidad adulta y que la historia se nos cuenta desde un tiempo presente.

Ubicados ya temporalmente en el flash back, la historia trascurre en una linealidad temporal sólo sobresaltada por los adelantos temporales que pasan a retratar las distintas edades de Adriana en la novela. Como hemos señalado, el verbo es siempre pasado en el relato literario, exceptuando el principio y el final de la misma, que nos recuerdan que dicho relato es en realidad una suerte de confesión, de recuerdo sobre el pasado desde el presente.

La división temporal básica de la novela nos lleva a tres espacios: el primero de ellos es el que ocupa la relación primigenia entre hija y padre, llena de amor del 
segundo a la primera y de adoración de la primera al segundo. Un segundo movimiento nos lleva al cambio en dicha relación y refleja la degradación del padre y la convivencia entre ambos. El tercer acto se produce en Sevilla y es la constatación de la vida secreta del padre y de la madurez de Adriana.

En la película de Erice, el segundo espacio temporal comienza con la vuelta al sur de Milagros y la madre de Agustín, e incluye el proceso de indagación de Estrella sobre el pasado de su padre, hasta el salto temporal comentado, producido en el camino que lleva a La Gaviota. La tercera parte, en que Estrella es ya una adolescente, concluye con el suicidio de Agustín, una vuelta a la escena inicial de ésta en su habitación y el viaje no mostrado de la protagonista hacia el sur.

La propia palabra en la novela y la voz en off en la película nos llevan a disociar dos tiempos: el de la enunciación propia de dichas palabras -el presente- y el tiempo de la acción que vemos escrita y filmada -el pasado-. En el relato escrito, ese pasado puede no ser tal, de hecho es más una recreación del pasado. En la película también podemos pensar en esa teoría, de hecho la voz en off puede llevar al espectador a pensar que dichas acciones puedan ser más ensoñaciones y pensamientos de la protagonista que hechos verdaderos.

La novela no indica concretamente el espacio temporal en que nos situamos. La película de Erice sí: Otoño 1957. Desde el principio, y con la primera luz del día, descubrimos a Estrella, y con el sonido fuera de campo entendemos ya la pérdida del padre. Si la novela comienza con el tuteo de Adriana madura a su padre:

"Mañana, en cuanto amanezca, iré a visitar tu tumba, papá" (García, 1985: 5).

la película lo hace con la voz en off de Estrella hablando de él en tercera persona:

"Aquel amanecer, cuando encontré su péndulo debajo de mi almohada, sentí que esa vez todo era diferente, que él ya nunca volvería a casa".

En ese sentido, nos parece muy acertada la reflexión de Cristina Martínez Carazo cuando afirma que: 
"Mientras que en la película se parte del amor paterno-filial, en el texto narrativo el punto de partida es ya el desamor, un momento posterior a la ruptura de la fascinación del padre, cuando la joven ya ha comenzado a vivir su propia vida, y ha adquirido un conocimiento basado en la soledad y el abandono, según puede inferirse muchas veces de lo no dicho"(Martínez-Carazo, 1997: 190).

Si no es el desamor, al menos sí aparece ya la desilusión, la comprensión de la naturaleza de un padre marcado por "una profunda amargura y una dureza implacable" (García, 1985: 6).

Las primeras explicaciones que obtenemos sobre el sur tienen que ver con la mala relación entre padre y abuelo, y las primeras imágenes de aquél las obtenemos a través de unas postales. La segunda referencia al sur la obtenemos con la aparición de la abuela y de Milagros:

"Desde ese día, cuantas veces evocara el sur, la imagen de aquellas mujeres acudiría siempre a mi memoria" (García, 1985: 20).

El Sur rompe la tendencia tradicional en la adaptación cinematográfica de no mostrar los saltos temporales. El uso de la cámara de Erice nos muestra el salto temporal o elipsis ejemplificado en un camino cambiante, el que recorre Estrella en su bicicleta y que, como ella misma, muestra el paso del tiempo y sus efectos en personajes y localizaciones.

\section{Enunciación y punto de vista}

Mucho se ha hablado y escrito del punto de vista y la enunciación en El Sur. Autores como Fernández Santos señala la incoherencia del primero por cuanto en ocasiones nos deshacemos de Estrella y su mirada para ver a un Agustín solitario. En este apartado intentaremos demostrar que tal incoherencia no es tal y que la voz narrativa en la película de Erice guarda relación no sólo con la utilizada en la novela que la da origen, sino también una coherencia interna en toda la cinta.

Conviene recordar la dificultad y la peculiaridad en la adaptación de un texto edificado en torno a un relato en primera persona, en base a un flash back explicado por la subjetividad de la propia protagonista. Adriana narra su 
pasado, recuerda su historia a través de un monólogo dirigido en primera persona a su padre.

Carmen Arocena asemeja El Sur literario a la novela El Extranjero de Camus y cita a F. Jost para explicar que ambas están narradas en focalización interna en ocularización cero; esto significa que

"La narración es objetiva desde el plano psíquico pero no desde el perceptivo. [...] El acento se pone sobre lo que pasa en la cabeza del personaje al que accedemos por medio de verbos de actitud preposicional” (Arocena, 1996: 201).

Estamos de acuerdo con Arocena en dicha comparación, y es que El Sur de García Morales es el resultado de la percepción de Adriana, una narradora adulta que recapacita sobre su pasado, que explora y explica sus sentimientos, no a nosotros, sino a su padre, en forma de confesión postrera:

"Mañana, en cuanto amanezca, iré a visitar tu tumba, papá” (García, 1985: 5).

A partir de esta frase, el relato constituye una exploración, una confesión introspectiva que terminará en el mismo punto en que empieza y después de un largo flash back, en la soledad de una mujer adulta que, durante casi cincuenta páginas, desgrana un tiempo pasado que marca su presente.

Veamos ya como dicha estructura y voz narrativa se refleja en la película de Erice. La palabra de Adriana tiene su correspondencia en la película en la voz en off de Estrella. El destinatario, en la novela el padre, no lo es en la cinta. Erice elimina el apelativo directo, del tú pasamos al él. La voz de Estrella adulta fuera de campo tiene la doble función de subrayar el carácter biográfico de la narración y de explicar los procesos cognitivos y perceptivos de la protagonista. Como hemos dicho, la voz en off pierde, respecto al texto literario, la apelación directa al padre, lo que hace al espectador receptor directo de las palabras de Estrella: pasamos de intrusos en la novela, de fisgones en las confesiones de Adriana a su padre, a receptores plenos en la película, a espectadores directos de la vida de Estrella, mediante la conexión con un narrador diegético y muy alejado del objetivismo. 
Es la voz de Estrella la que nos introduce en la historia, es también quien nos presenta al padre, destinatario principal de sus reflexiones, y quien nos introduce en el largo flash back que nos llevará a la primera infancia de la misma. Lejos de resultar redundante con las imágenes, la voz en off subraya los procesos mentales de Estrella, nos hace partícipes como espectadores de un relato intimista y un proceso de maduración, de indagación, de descubrimiento.

Adriana es, en todo caso, una narradora homodiegética por ser, además de ello, personaje de su propia historia. El personaje cumple las funciones narrativa, comunicativa -interpelación directa con el destinatario, el padre-, ideológica puesto que la historia nos llega a través de sus ojos, tamizada por su propia visión de las cosas, por su propia idea acerca de los acontecimientos- y testimonial -la afectación de la historia en Adriana como narradora es incuestionable-:

"Yo no podía hablar. Una emoción intensa y extraña vibraba en todo mi cuerpo" (García, 1985: 12).

Volviendo a la teoría de la incoherencia del punto de vista en la película, Fernández Santos asegura qué esta se debe a que en ocasiones en la misma abandonamos el punto de vista de Estrella (tal es el caso de la escena en el cine, cuando acompañamos a Agustín dentro de la sala o cuando vemos a éste leer sólo en un bar las cartas de Irene Ríos) para adoptar otro.

Nos parece que esta tesis peca de algo parecido a la que sostiene que El Sur fílmico adolecerá siempre de un final apropiado por no estar rodada la parte correspondiente al viaje de Estrella al sur: el lenguaje cinematográfico tiene herramientas y mecanismos que lo hacen diferente al literario; de tal forma, al igual que señalábamos que el Sur es una película terminada, redonda y que ha de saberse ver con independencia del texto literario del que proviene, parece justo señalar que la cámara en el cine puede separarse de la figura protagonista, por mucho que ésta aparezca como narradora y por mucho que su voz en off sea la que acompañe a las imágenes. Dicho de otra forma, nos parece que la especificidad del medio cinematográfico permite la disociación en ciertos momentos del punto de vista de la protagonista como narradora y observadora. Pedro Poyato lo explica de la siguiente forma: 


\section{"[...] El enunciador fílmico aparece en el discurso enunciado} escindido en un narrador que, desde el presente, cuenta y un observador que, desde el pasado, muestra" (Poyato, 20oo: 133).

En efecto, si bien en el texto literario la figura del enunciador es también la del narrador, en el texto fílmico éstas se bifurcan, dando lugar a una diferenciación entre Estrella narradora, como mujer adulta que explica las imágenes que vemos como espectadores, y Estrella observadora que, desde la mirada del presente de las imágenes, nos acompaña en el descubrimiento de su relación con su padre.

El narrador en la novela, en este caso uno único encarnado en la figura de Adriana adulta, no es un narrador omnisciente. $\mathrm{Al}$ contrario, Adriana habla de sus propias percepciones y, en muchos casos, reconoce no saber el porqué del comportamiento de su padre y de otros personajes, mucho menos las causas de su cambio de carácter o de su pasado. Todo esto matizado, eso si, por los saberes añadidos que otorga la narradora el hecho de hablar desde la perspectiva de una mujer ya adulta que, con el paso de los años, ha logrado adivinar parte de ese misterio y esa historia.

En cuanto al lenguaje narrativo de Erice, sus planos largos, su pausa, su tranquilidad y su contemplación casan perfectamente con el carácter propio de una relato que, por cinematográfico, no abandona algunas de las pautas que lo hacen deudor de su origen literario: el espectador se identifica con esa historia lenta, reflexiva y, al igual que hace con un libro, se detiene, reflexiona. El carácter autobiográfico de la novela explica que no haya diálogos, con lo que la adaptación cinematográfica inventa, o adapta, mediante la trasposición de los pensamientos de Adriana en el texto literario, los diálogos en la película.

\section{Conclusiones}

Hemos tratado de analizar $E l$ Sur de Erice en su relación con la obra de origen y de demostrar cómo, más allá del carácter inacabado, inconcluso, que sabemos tiene la película, se puede analizar desde el prisma de una película completa, redonda, por lo que es, $\mathrm{y}$ no por lo que pudiera haber sido. 
La literatura, con sus armas, y el cine, con las suyas, se encuentran inmejorablemente en una película que respira cine por todas sus escenas, pero que ni niega ni esconde una herencia literaria, un modo de narrar pausado, una detención en los detalles y un espíritu metafórico y lírico.

No se puede expresar mejor de lo que lo hace Antoine Jaime,

"El Sur se ve como se lee un libro, con el placer del cine añadido"

(Jaime, 2000: 268).

Pensamos que es hora de valorar El Sur como lo que es, una película acabada e imperdible dentro del cine español que, para bien o para mal, se desarrolla en un espacio único, pero que en absoluto carece del impacto emocional y simbólico que pretende y algunos autores le niegan. Se trata de una cinta fascinante que compensa las lagunas y ausencias de guión con altas dosis de buen cine, de realización genial.

Una vez estudiados los aspectos narrativos, enunciativos, espaciales y temporales de ambas, se puede hablar de una adaptación fiel en cuanto al espíritu de la cinta, no exacta en su presentación de personajes ni lugares, pero sí excelsa en la adaptación de un universo literario especialmente complicado por su subjetividad.

\section{Referencias bibliográficas}

AgUStín MAHIEU, José (1984). Víctor Erice. En Cuadernos hispanoamericanos, $n^{\circ} 411$, pp. 85-101.

AROCENA, Carmen (1996). Víctor Erice. Madrid: Cátedra.

CASTRILLÓN, José Luis y MARTÍN, Ignacio (2000). El cine de Víctor Erice. Valladolid: Caja España.

CERRATO, Rafael (2006). Víctor Erice. El poeta pictórico. Madrid: JC.

ERICE, Víctor. (2003). Regreso al Sur. Entrevista a Víctor Erice. Consultado el 14 de mayo de 2011 en http://www.rtve.es/noticias/20110106/victorerice-sur-nunca-estuvo-planteada-como-dos-peliculas/393001.shtml

EVANS, Jo (1995-1996). A Myth in Time: Victor Erice's El Sur. En Journal of Hispanic Research, vol. 4, pp. 147-157. 
FERNÁNDEZ, Ángel (1983). 33 preguntas eruditas sobre El sur. En Casablanca, vol. 31/32, pp. 55-58.

GARCÍA, Adelaida (1985). El Sur seguido de Bene. Barcelona: Anagrama.

JAIME, Antoine (2000). Literatura y cine en España (1975-1995). Madrid: Cátedra, 2000.

JOSÉ DÍAZ, Epicteto (2008). Imágenes de la soledad en El Sur y Bene de Adelaida García Morales. En Revista de Literatura, vol. LXX, nº 139, pp. 223-237.

MARTÍNEZ-CARAZO, Cristina (1997). El Sur: De la palabra a la imagen. En Bulletin of Hispanic Studies, vol. 74, 2, pp. 187-196.

MARTÍNEZ-CARAZO, Cristina. Novela española y cine a partir de 1939. California: University of California.

MÍNGUEZ, Norberto (1998). La novela y el cine. Análisis comparado de dos discursos narrativos. Valencia: Contraluz.

MíNGUEZ, Norberto (2002). Figuras sureñas y otras ausencias en El Sur de Víctor Erice. En MÍNGUEZ, Norberto (ed.). Literatura española y cine. Editorial Complutense, pp. 113-129.

POYATO, Pedro (2000). Introducción a la teoría y análisis de la imagen focinema-tográfica. Madrid: Grupo Editorial Universitario.

TALAVERA, Sebastián (2007). En el Mundo, El Sur. En Frame, no 1, pp. 178185.

TRAZEGNIES, Leopoldo (2007). El desamor de un ególatra. En El País. Consultado el 23 de mayo de 2011 en http://www.trazegnies.arrakis.es/sur.html 